\title{
THE APPLICATION OF NEO(NEO)FUNCTIONALIST THEORY TO JUSTICE AND HOME AFFAIRS
}

\section{Catherine Macmillan*}

Abstract: This paper attempts a neofunctionalist appraisal of the development of Justice and Home Affairs, which has been one of the most dynamic EU policy areas in recent years. It argues that neofunctionalism can explain the increasing supranationalisation of this policy area despite the fact that internal security has traditionally been conceived as an integral part of national sovereignty.

Keywords: JHA, Neofunctionalism, Spillover

Özet: Bu makalenin amacl, son yıllarda AB'nin en dinamik alanlarindan olan Adalet ve İçişlerinde İşbirliği ile ilgili gelişsmeleri Yeni İşlevseci yaklaşımı kullanarak çözümlemektir. İ̧ güvenlik konuları ulus devletin egemenliğin ayrlmaz bir unsuru olarak görülmektedir. Makale, buna rağmen Adalet ve İçişlerinde İşbirliği alanındaki gelişen uluslarüstü yapıya geçişi Yeni İşlevselci yaklaşımın açıklayabileceğini savunmaktadır.

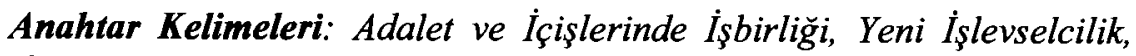
yaylma

\section{Introduction}

Justice and Home Affairs has been one of the fastest-growing policy areas in the EU in recent years. From its humble roots in the Trevi agreement of the 1970s, JHA is now at the forefront of EU activity. Moreover, JHA has become considerably supranationalised since the Maastricht Treaty, when decision-making was largely intergovernmental. This is almost astonishing when it is taken into consideration that, for centuries, internal security and border policies were considered to be an essential part of a nation state's sovereignty (Monar, 2005: 1). Explaining the Member States' agreement, and sometimes enthusiasm, to hand over large amounts of sovereignty to the EU in an area that was considered 'high

\footnotetext{
${ }^{*}$ Dr., Yeditepe University Department of English Language and Literature
} 
politics' until recently has therefore been a challenge for many students of European integration.

\section{A Quick Overview of Neofunctionalist Theory}

\subsection{The Concept of Spillover}

Although based on Mitrany's functionalism, according to which interest shifts automatically from the national to the supranational arena, neofunctionalism argues that this process requires a certain amount of political action. This may be in response to a crisis in the integration process, which national actors seek to resolve by spillover, or co-operation in new policy areas (Schmitter, 2002: 15). In neofunctionalism, then, the default outcome for integration between states in order to solve a common problem does not involve either a loss of state sovereignty or task expansion. This outcome, known as encapsulation, can be seen, for instance, in many international organisations, which remain strictly intergovernmental in nature (Schmitter, 2002: 15).

For this reason, then, according to neofunctionalism, certain background conditions are required for integration to break out of its capsule, such as shared basic values, a certain degree of homogenity in levels of political, social and economic development, a network of transactions, comparable decision-making processes and compatibility of expectations (Groom, 1994: 114). Moreover, neofunctionalism argues that it is important that the tasks assigned to the organisation are inherently expansive, as only in this way can spillover occur (Lindberg, 1994: 107).

There must also be a shared belief that integration will lead to an increased satisfaction of needs and a belief at both mass and elite level that problems can be solved in a mutually acceptable way (Groom, 1994: 114). Haas argued that spillover could occur if mass support was knowledgeable, and therefore supportive of, the benefits of integration, while national elites would support integration if they considered that it would serve their own best interest. This concept was later refined to suggest that the perceptions of the benefits, and of low costs, of integration were important, while the perception of an external threat could also be influential (Moxon-Browne, 2003: 93).

If intergovernmental co-operation were to prove ineffective, and these background conditions were fulfilled, then, the members concerned may 
decide to opt for new strategies re-evaluating both the level and scope of cooperation and perhaps even adopting a new set of objectives, i.e. moving from economic to political integration (Bainbridge, 2001: 299).

Therefore, in common with functionalism, neofunctionalism predicts that, provided that these background conditions are fulfilled, co-operation in one area will produce a spillover effect resulting in co-operation in related areas. It differs from functionalism, however, in that according to neofunctionalism, spillover, as well as being 'semi-automatic', may also be 'manually operated', as interest groups within Member States push for further integration. This spillover can be divided into three different types as follows:

Functional spillover: Projects of integration engender new problems which, in turn, can only be solved by further integration (TranholmMikkelsen, 1991: 4-6). While this was originally conceived as taking place in the area of economics, economic integration may foster not only deeper economic integration but may, eventually result in political integration, as deeper economic integration would require a degree of supranational regulation (Tranholm-Mikkelsen, 1991: 60).

However, according to neo-neo functionalism, perhaps the most recent 'incarnation' of neo-functionalism, and other newer versions of neofunctionalism such a process may also be set in motion as a reaction to tensions in the global environment as well as previous integration projects, providing that the background conditions discussed earlier are suitably fulfilled (Schmitter, 2002: 32-33).

Political spillover: This occurs when elites (both governmental, such as bureacracies and non-governmental, such as trades unions or leaders of political parties) begin to percieve that their interests may be better served by supranational institutions than by their nation states and, consequently, refocus their activities towards these institutions (Tranholm-Mikkelsen, 1991: 4-6). As a result, as the integration process develops, national actors appear to be less of a homogenous unit with a single integrative or disintegrative strategy, and seem to become fragmented into various negotiating units (Schmitter, 2002: 35) which may hold different positions during any integration crisis. Thus, the various governmental and nongovernmental national elites become actors in their own right at the EU 
level, and may support integration strategies different from those upheld by their government.

Political spillover is also promoted by the complex system of engrenage which has taken place between national and EU bureacracies, and which is difficult for national governments to control (Groom, 1994: 4-6). Moreover, as nationally based interest groups realise that their interests are beter served by Brussels, they also begin to lobby their governments accordingly. The net result would be an increase in support for integration on the part of national political systems (Rosamond, 2000: 59).

Although it has generally been assumed that political spillover was an exclusively elite phenonemon, it has more recently been suggested that public opinion may also play an important role in moving integration 'along the continuum from intergovernmentalism to supranationalism'. While it has long been taken for granted that policy making at EU level takes place behind closed doors, and that public opinion, due to the democratic deficit, therefore has little impact, recent research has shown that elite and public opinion may show less divergence than was previously assumed (Lahav, 2004: 11-17).

Support for integration at mass level, however, appears to be most closely linked to perceptions of the effects of integration rather than objective conditions as pulic opinion may be distorted by political elites' attempts to gain credit and apportion blame for these developments (Marsh, 1999: 198). For this reason then, public opinion, although it has generally not been taken into consideration by European integration studies until recently, will also be taken into account in this evaluation.

In addition, political spillover may be centred on the other supranational institutions apart from the Commission. NGOs, for instance, may focus their lobbying on the European Court of Justice (ECJ) and European Parliament (EP) as well as the Commission. This has been particularly emphasised by Schmitter's neo-neofunctionalism. While traditional neofunctionalists consider that the finalite politique of neofunctionalist spillover is a federal state, Schmitter, for instance, argues that this is not necessarily so, and that the end result may instead be a regional organisation dominated by multilevel and poly-centric governance (2002: 39).

The ECJ appears to be particularly important in this regard. As Mattli and Slaughter point out, 'Pressure groups have made use of greater rights 
under Community law than under national legal rules to play a significant part in the development of substantive Community law, particularly in employment law and gender equality' (1996). Lobbying aimed at the EP, on the other hand, is usually carried out in areas where the EP has the right of co-decision, and therefore an effective veto (Wessels, 1999: 109).

Cultivated spillover: Neofunctionalism supposes that, over time, supranational institutions are likely to develop an increasingly independent identity, with ideas of their own that cannot simply be reduced to the preferences of a single national or subnational group. Therefore, supranational institutions themselves may seek to encourage further integration (and meanwhile strengthen their own power-base) by encouraging co-operation in areas which are perceived to have a common interest. They may do this by cultivating functional or political spillover or by cultivating integration more generally (Schmitter, 2005: 260).

Haas suggested that, while intergovernmental bargaining rarely went beyond a 'lowest common denominator' solution, the presence of an intermediary, such as the Commission, may result in 'upgrading the common interest' and, consequently in further integration (Groom, 1994: 46). However, it should be emphasised here that, while most cultivated spillover may be centred on the Commission, the role of the ECJ in this regard has been frequently underestimated. In reality, it favours integration as well as ruling on the basis of legal arguments (Stroby-Jensen, 2003: 87). Therefore, and, due to the primacy of EC law and the ECJ's frequently 'imaginative interpretations of specific treaty provisions', it has also had a significant influence in shaping policies (Schmitter, 2002: 12).

The EP is also expected, according to neofunctionalism, to have a supranational orientation and to develop loyalties to the EU which often override national interests (Stroby-Jensen, 2003: 87). According to Lahav's survey of MEPs this appears to be true, although she points out that while MEPs are generally pro-integration, they differ in the amount and speed of integration that they support (Lahav, 2004: 165).

Moreover, although it can be argued that the power of the EP to cultivate spillover was severely curtailed until recent years by its lack of a decisionmaking role, the gradual introduction of co-decision since the Maastricht Treaty has given it new opportunities for action. In addition, despite the rejection of the Constitutional Treaty, the EU public appears to continue to 
demand more transparency and democracy in decision-making, making it likely that the EP will become even more of a key player in the years to come.

\subsection{Not Just Integration: Counterveiling Forces in Neofunctionalism}

Early proponents of neofunctionalism such as Haas and Lindberg assumed there was no going back once the process of spillover had been initiated, and, moreover, that the process was bound to gain momentum. They certainly saw little evidence, in the early days of the European Communities, that the system was in any danger of collapse (Rosamond, 2000: 63). By early 1965, then, prior to the De Gaulle's Empty Chair Crisis, developments in the EC seemed to bear out the neofunctionalist hypothesis. Indeed, Haas was able to state that the $\mathrm{EC}$ had 'come close to voiding the power of the national state in all realms other than defence, education and foreign policy'(Caporaso and Keeler, 1995: 36).

The stagnation in integration that began with the 'Empty Chair Crisis' and continued throughout the 1970 s and early 1980 s provoked a crisis in neofunctionalism, with even Haas himself describing the theory as 'obsolete'. It became clear, as a consequence of the 'Empty Chair Crisis' and the resulting Luxembourg Compromise, that governments could, and in some cases would, try to stop further attempts at integration. Although it was premature to announce the demise of neofunctionalism, at this point the theory did lose some credibility, and it was significantly reworked as neofunctionalist scholars realised that they had underestimated the role of nationalism in defining European integration. One of the most important concepts to come out of these studies was that of 'spillback', a retreat of integration either at sectoral, or institutional level, or both (Rosamond, 2000: 64-65).

Niemann (2006: 13) suggests that spillback may result from three basic counterveiling forces to integration. Spillover may be stalled by leaders, such as De Gaulle and Thatcher, who are especially wary of handing over sovereignty to supranational institutions. Such an attitude may be cultivated, or it may result from national traditions and identities.

In addition, governments may be constrained by domestic groups, including lobby groups, opposition parties, the media or public opinion, as well as by structural limitations. As this may prevent the government in question, even if it is itself pro-integration, from rising above a certain 
common-denominator, this may have a negative effect on integration (Niemann, 2006: 13).

Finally, diversity may have a negative effect on integration as common positions or policies may require one or more MS to depart from deeplyrooted structures, customs or policies. Such diversity is, of course, reinforced through the enlargement process (Niemann, 2006: 13-14).

As well as spillback, another alternative reaction to spillover was that of 'muddle-about', in which actors try to maintain their integration without institutional changes. Other possible outcomes include 'spill-around', the proliferation of functionally specialised, independent but strictly intergovernmental bodies and 'build-up', the granting, by MS, of greater authority to a regional organisation without expanding its mandate (Schmitter, 2002: 32).

Indeed, some later neofunctionalists such as Schmitter argue that spillover is fairly unlikely to result from a crisis in integration. According to this view, such a crisis is far more likely to result in encapsulation, or an intergovernmental solution, although the chances of spillover increase according to the previous level of integration of the regional organisation. Only if the background conditions are fulfilled and encapsulation fails to address the problem will other solutions (one of which may be spillover) be sought (Schmitter, 2002: 32).

However, with hindsight, it can be argued that neofunctionalism has actually been enriched by this challenge. As Schmitter points out;

Any comprehensive theory of integration should potentially be a theory of disintegration: it should not only explain why countries decide to co-ordinate their efforts across a wider range of tasks and delegate more authority to common institutions, but also why they do not do so or why, having done so, they try to defect from such arrangements (2002: 1).

\section{A Neofunctionalist Analysis of Justice and Home Affairs}

\subsection{Functional Spillover}

According to neofunctionalist theory, functional spillover may occur when earlier integration initiatives have knock-on effects which also need to be tackled at the level of the regional organisation. In the case of JHA, then, when searching for functional spillover, the first step would be to examine if 
the development of such policies at EU level could be explained as a consequence of earlier EC/EU initiatives.

Indeed, it can be argued that, to a certain extent, the development of the EU's border policies is a direct result of earlier EC/EU integration policies such as the Single Market and the Schengen agreement. The decision to dismantle internal borders in the Schengen area can be viewed as an extension of the logic of the free movement of people, an inherent part of the concept of the Single Market (Walker, 2004: 19).

Meanwhile, particularly in the more unstable atmosphere following the collapse of Communism to the EU's East, it was thought necessary to compensate for the dismantling of internal borders with increased vigilance at the external borders, resulting in the creation of over 20 new intergovernmental bodies dealing with JHA issues between 1986-1991. Moreover, it was argued that despite the completion of the Single Market, it was still difficult for businesses and individuals to gain access to adequate judicial representation in other Member States (Monar, 2000: 755).

This situation meant that governments were increasingly affected by each others' decisions relating to immigration and border controls, and were therefore ready to co-operate in an area which had traditionally been seen as 'high politics'. While the earliest attempts at co-operation were largely intergovernmental in nature, governments were gradually forced to acknowledge that effective decision-making in this area needed a more supranational approach.

On the one hand, the absence of the Commission as an independent agenda-setter meant that governments themselves had to come up with legislative proposals, which often promoted the narrow national interests of the governments concerned. On the other, it was becoming clear that the use of unanimity was hampering decision-making in an area where decisions often need to be taken quickly (Hix, 1999: 323). Moreover, there was, and still is often infighting between government ministries, particularly foreign affairs and interior ministries, which made, even for a single Member State government, arriving at a coherent position on JHA issues difficult at times (Guiraudon, 2001: ). In addition, Member States, particularly those participating in the Schengen Agreement, now recognised that they were affected by each other's choices regarding refugee, immigration and policing policies and therefore had an interest in developing a more supranational regime in order to avoid 'the pitfalls of collective action 
problems' (Lahav, 2004: 50). This, then, partly explains the willingness of the European Council at Amsterdam and, later, in the negotiations for the Constitutional Treaty to accept an increasing communitarisation of JHA.

Moreover, a rather more cynical view is the 'Europe to the Rescue', or what may also be dubbed the 'Blame it on Brussels' approach. According to this concept, Member States governments are eager to hand controversial or contentious policies, such as migration or asylum policy in particular, to the $\mathrm{EU}$ in order to escape attacks by their domestic adversaries or the general public (Lahav, 2004: 49).

However, other seemingly unlinked, policies have also resulted in functional spillover to JHA. An example is the introduction of the Euro, which resulted in Europol being granted more responsibility for tackling counterfeiting. In addition, the 1999 Helsinki summit's decision to speed up the creation of a European Rapid Reaction Force also spilled over into JHA as civilian police units were to carry out some of the Petersberg tasks relating to peacekeeping and nation-building (Occhipinti, 2004: 187)

\subsection{Political Spillover}

If we were to find evidence of political spillover in the development of JHA, we would expect to find national elites, perhaps pushed to a degree by pressure from the general public, looking increasingly towards EU supranational institutions, rather than to their nation state, for leadership in this area.

This, in general, seems indeed to be the case. On the one hand, it is apparent that, since the mid-1990s, there has been a significant change of voters' attitudes towards JHA. Whereas before it was largely viewed as a high-politics issue which should be left in the hands of the Member States, since around the time of the Amsterdam IGC JHA has been percieved as an area in which the EU should take further action. This is borne out by a Spring 1996 Eurobarometer report in which free movement of persons and internal security were high on the list of respondents' demands for more EU action (Hix, 1999: 323-324).

A more recent series of questionnaires carried out for Eurobarometer on the subject of JHA also backs up the idea that there is significant public support for integration in this area as opposed to other policy fields. Moreover, this support is extended both to the immigration and asylum 
policies and to co-operation in police and judicial affairs, with an overall approval rating of between $56 \%$ and $90 \%$ according to the question (Eurobarometer, 2004: 5-34).

However, it has also been argued that sectors of the European public have been critical of the increasing secrecy and unaccountability which characterised JHA co-operation, at least up until the Amsterdam Treaty. As a result, and in tandem with institutions such as the EP, public dissatisfaction with the opaque nature of decision-making in JHA led to pressure for the creation of the AFSJ, which was supposed to be based on the principles of democracy and transparency (Eder and Trenz, 2003: 112113). In this case, therefore, public opinion appears to have contributed directly to spillover in this area.

Pushed therefore either by public opinion or other motives, various actors have been attracted to increased EU co-operation or integration in JHA. As Guiraudon points out regarding immigration policy, however, the actors involved and the policy outcomes they support are disparate:

In this motley crew, we find law and order officials from Interior, Justice and Foreign Affairs ministries, international NGOs, activists and Commission fonctionnaires from different directorates. Although each in its own way came to believe that immigration policy should become 'Europeanized', they exploited different venues and policy frames resulting in a set of policy instruments involving varying degrees of supranationalization or decision-making rules (2001: 4).

The first group of actors to 'go transnational' were law and order officials in charge of border and migration control, who tended to favour migration control over positive migration or integration strategies. Guiraudon argues that, finding themselves increasingly constrained at national level due to an increase in pro-migrant legislation during the 1980s, they began to seek new policy venues, namely the Schengen agreement and the early 1990s transgovernmental agreements on immigration and asylum (2001: 8-9).

It has also been argued that the threat posed to interior and justice ministries by the relaxation of border controls as part of the Single Market programme also played a part in their switching attention to the European level. Faced, therefore, with a loss of resources and revenue from customs duties, interior and justice ministers across the EU produced reports arguing 
that there was a major danger of cross-border crime as a result of the Single Market ${ }^{1}$. These scaremongering reports were designed to frighten politicians into granting more resources to their ministries (Hix, 1999: 325).

Meanwhile, Guiraudon suggests that the decision to 'supranationalise' large sectors of JHA in the Amsterdam Treaty was actually partly due to 'revenge' against the Justice and Interior ministries on the part of Foreign Affairs ministries which are, of course, responsible for negotiating treaty revisions (Guiraudon, 2001: 11). That is, there is evidence of competition between the Ministries of Foreign Affairs and those of Justice or the Interior for influence at the European level.

As an aside, it is interesting that this is exactly what Schmitter's neo-neo functionalisn predicts will happen once the EU has entered a 'transformation cycle', or the final stages of integration. In Schmitter's own words:

A new regional change process could well emerge. Let us call it the Domestic Status Effect. The redefined scope/level of regional institutions will tend to affect relative status and influence in the domestic politics of its member states. Ministries, autonomous agencies, associations and parties that have 'gotten in on' the earlier rounds of regional decision-making will have acquired more resources (proportion of the budget, regulatory capacity, international status, votes, etc.). This should cause other national institutions to try to 'get in on' the operation, although not necessarily in support of it (Schmitter, 2002: 35).

Moreover, as Geddes points out, iterative interaction, or a 'wining and dining culture' at a European level can affect the prefererences and identities of actors, both ministers and officials, who take part in EU level policy forums. In addition, in cases where actors, particularly judges and bureaucrats, are shielded from direct electoral pressure by the EU's 'democratic deficit', this may offer scope for more liberal outcomes, emphasising migrants' rights rather than immigration control (Geddes, 2003: 4-5).

At the same time, perhaps as a reaction to the increasingly restrictive development of migration policy at European level, both national and

\footnotetext{
${ }^{1}$ In fact, according to statistical evidence, there has only been a moderate increase of international crime and the movement of persons as a result of the Single Market.
} 
Brussels- based NGOs have also been active in lobbying for more supranational policy making in the areas of migration and internal security. Their argument is that intergovernmental decision-making is often secretive, and that this implies a lack of parliamentary and judicial control (Hix, 1999: 328-329), in other words a 'democratic deficit'.

Pro-migrant NGOs, such as the Migrants' Forum, Migration Policy Group and Starting Line have been particularly active at EU level. These organisations, which are relatively weak at national level due to the fact that public opinion across the EU tends to be anti-immigration, have increasingly turned towards the European Commission and ECJ, where, arguably, decision-makers are still relatively shielded from public opinion due to the democratic deficit. In this way, these NGOs aim to use the example of the EU, with the power and authority associated with it, to challenge national ways of dealing with immigrants (Geddes, 2003: 8-9).

Moreover, developments in the EU acquis can also help to account for the increase in lobbying at EU level on the part of these organisations. Firstly, with the Maastricht Treaty's granting of rights to EU citizens, it can be argued that the gap between EU citizens and resident Third Country Nationals (TCNs), who were not granted EU citizenship, has widened. Secondly, these groups have used the EU's 'war on social exclusion' to lobby for more rights for migrants, arguing that TCNs are among its prime victims (Guiradon, 2001: 18-19).

In addition, it can be argued that political spillover has been centred on the ECJ as well as the Commission. As has already been pointed out, Mattli and Slaughter have suggested that NGOs tend to influence EC legislation by taking advantage of comparatively greater rights at EU than at national level (1996). Luedtke has argued that this is what has happened regarding TCNs. As some TCNs have been granted the right of free movement as a consequence of being married to an EU national, working for an EU firm or because of association agreements, NGOs have argued that it is unsustainable to exclude other TCNs from this right (2005).

In conclusion, then, there has been considerable political spillover in the area of JHA, with the general public, officials and lobbies increasingly acting, and calling for more action, at European level. However, while there is almost unanimous support among these groups for more action at EU level, there is disagreement on the nature of the kind of action to be taken. 
While the general public and law and order officials are calling for a security-oriented, restrictive border policy, officials more shielded from electoral pressure, as well as NGOs, tend to support more liberal policy outcomes focusing on migrants' rights.

\subsection{Cultivated Spillover}

Finally, the development of JHA also shows some evidence of cultivated spillover. Despite the fact that it was almost excluded from JHA according to the Maastricht arrangements, the Commission has consistently lobbied for more power in this policy area. It has done this largely by aiming to persuade governments to delegate the right of initiative to it by consistently coming up with policy proposals and ideas. Moreover, the Commission sucessfully put pressure on Member States to give it more powers by arguing that its lack of an agenda-setting role was a major contributor to the lack of progress in this area (Hix, 1999: 327-38).

An example of this is the Commission's proposals regarding the reform of the JHA pillar, presented to the Amsterdam IGC. In these, it particularly criticised the use of unanimity in JHA decision-making, arguing that this was slow and cumbersome. Moreover, it argued that the limitations on the Commission's right of initiative made it reluctant to use it, thereby further slowing policy development. Therefore, it advocated qualified majority voting (QMV) and an exclusive right of initiative for the Commission in order to speed up policy-making progress while, of course, giving the Commission itself a more active constitutional role in JHA (Uçarer, 2001: 9).

The result of this is that the constitutional powers of the Commission as an agenda-setter in JHA have gradually increased. Starting from practically no involvement at all in the Trevi group or the intergovernmental agreements on asylum in the early 1990s, it progressed to a shared right of initiative in the Maastricht Treaty, to sole right of initiative today. As expected, the Commission has generally shown a more pro-integration stance in this area than the Member States themselves, with, so far, only relatively few of the Commission's proposals being translated into law (Apap and Carrera, 2003: 8).

In addition to its formal agenda-setting powers, the Commission has also been adept at using its informal agenda-setting powers, defined by Geddes as including the highlighting of problems, advancing proposals, and 
identifying the possible material benefits of integration. Moreover, the Commission's capacities as an informal agenda setter have gradually increased as its institutional ability to deal with JHA have increased, particularly with the creation of the JHA DG (Uçarer, 2001: 9).

An example of informal agenda-setting is the Commission's emphasis, even in the post-September 11 atmosphere of increased securitisation of immigration, on co-ordination of labour migration rules between Member States, and on the development and co-ordination of integration policies for immigrants. This is reflected, for instance, in its 2003 communication on immigration, social policies and integration (Moraes, 2003: 124-127).

In this context, the Commission has argued, with some reason, that it has taken both a longer-term and a wider view of migration policy and has paid more attention to maintaining human rights standards in this area. This is despite the fact that, from the point of view of most national governments and the majority of the European public, preventing illegal immigration has been seen as much more of a priority, particularly since September 11, as could be seen in the 2002 Seville Council.

In addition, the Commission has sought, arguing that common problems need Europe-wide solutions, to 'advertise' itself as the co-ordinator for national action plans for 'positive' migration, including the management of migration flows, admission of economic migrants, partnerships with third countries and the integration of TCNs. This can be seen, for example, in its proposal to co-ordinate migration policies made in its July 2001 communication. In this way, then, the Commission can be seen to attempt to increase its power in this area by offering its services as an information store and co-ordinator (Geddes, 2000: 7).

The Commission has also aimed to increase its influence in JHA by funding national and sub-national lobby groups representing migrants, and thereby adding to them a European, supranational dimension. For instance, during the period 1991-1993, when the Maastricht Treaty had not yet been signed and European immigration and asylum co-operation was, in theory, entirely intergovernmental, the European Commission was already funding 500 such projects (Geddes, 2000: 143-144).

In addition, the Commission's activism in JHA has not been limited to migration and asylum policies. The Commission has also pushed for a certain amount of supranationalisation in police co-operation, an area that, 
due to the association of the use of force with national sovereignty, is still very much intergovernmental in nature. In a 2002 communication, for instance, the Commission argues that a common framework for both interational police and judicial co-operation is necessary. Moreover, although it considers that co-operation between national police forces is sufficient to reach most of the goals, it points out that the issue of the democratic and judicial control of Europol must also be resolved (Fijnaut, 2004: 278). In this case, then, although it uses a rather diplomatic language which appears to support the idea that police co-operation should remain intergovernmental in nature, the Commission actually appears to be arguing here for a certain amount of supranationalisation of police co-operation. By suggesting that co-operation between national police forces is enough to achieve most goals, it is also hinting that it is not sufficient to reach all of them. As well as this, by bringing up the issue of democratic and judicial control of Europol, it seems to be advocating the involvement of the European Court of Justice and the European Parliament.

However, although the Commission has been the most active of all the supranational institutions in this field, there is also evidence for some limited cultivated spillover on the part of the Court of Justice. This is despite the fact that the Member States specifically did not grant the ECJ jurisdiction in JHA. As Mattli and Slaughter point out, there are two ways in which Community law can penetrate into the domestic law of the MS. The first of these, known as formal penetration, involves the expansion of areas covered by supranational jurisdiction. The second results from the spillover of Community legal regulation from the economic domain to social and political issues (Luedtke, 2005).

As has already been mentioned, the ECJ still has relatively little formal power in the area of JHA, although it was granted a limited jurisdiction in the Amsterdam Treaty. Firstly, the ECJ does not have direct effect in matters relating to TCNs. Secondly, the ECJ was also denied jurisdiction in all areas of border control relating to internal security and law and order, although the ECJ can define what fits these criteria itself After the Amsterdam Treaty the ECJ was given jurisdiction when national courts of 'final instance' requested rulings ${ }^{2}$, althugh this still implies a limited role.

\footnotetext{
2 This is not, however, equivalent to direct effect, according to which any national court can request an ECJ ruling.
} 
Despite the limitations of the ECJ's formal role in JHA, Luedtke argues that the institution has managed to gain some power to legislate over TCN immigrants due to its jurisdiction over free movement of workers. This is, then, spillover from the economic domain to social and political issues. As Luedtke points out, 'If we can find evidence of the Court making use of this role to eventually grant TCNs free movement rights against the wishes of national politicians, then we can say that spillover ... has occurred' (2004: 10-11).

Firstly, according to the ECJ, TCN family members of EU nationals are entitled to the same residence, work and welfare rights as EU citizens. Moreover, the ECJ may interpret 'spouse' to include same-sex partners, in which case free-movement rights could be extended to TCN same-sex partners of EU citizens, which is explicitly against the wish of many MS (Luedtke, 2004: 16-17).

Secondly, the ECJ has ruled in the 1990 Rush-Portugesa case that TCN employees of EU companies cannot be refused entry to another EU Member State on the grounds that immigration from non-EU states is a matter of national sovereignty. In this way, then, TCNs gain free-movement rights if they are employed by an EU firm. Moreover, in addition to using its capacity to legislate on the Single Market in order to grant TCNs freemovement rights, the ECJ has also used, in some cases, association agreements to grant $\mathrm{TCNs}$ the rights to free movement and social entitlements (Luedtke, 2004: 14 ). Moreover, although these rulings on the part of the ECJ seem to have a very limited effect as they only apply to a relatively small proportion of TCNs, their actual consequence may be greater. This is because pro-migrant NGOs are arguing that it is untenable to extend rights of free movement to one group of TCNs while excluding the rest.

Finally, there has also been some evidence of cultivated spillover on the part of the EP in the area of JHA. Neofunctionalist theory expects the EP to be a supranationally oriented institution, in favour of European integration (Stroby Jensen, 2003: 87). The EP, then, has generally been in favour of increased supranationalisation of immigration and asylum policies and of less restrictive policies. It can therefore be seen to be a natural ally of the other supranational institutions, most notably the Commission, and lobby groups in aiming towards this goal (Geddes, 2003: 143). However, due to its relatively limited official powers in JHA, the EP has mainly been active in 
putting pressure on national governments and other EU institutions to act in this area. This is not to say that the EP has not sought greater power for itself in this area. The EP has continuously argued that there was a democratic deficit in this policy domain as decision-makers were no longer accountable to national parliaments, and that, in consequence, more powers of scrutiny should be granted to the EP. However, at the 1996 IGC Reflection Group, the EP pursued a 'minimalist' strategy, arguing that it should have the right of consultation (rather than co-decision). This, in turn, was accepted by the Member States due to the limited nature of the demand and the percieved reduction in the democratic deficit that this would bring (Hix, 1999: 328).

Like the Commission and the ECJ, the EP has also been critical of intergovernmental asylum and immigration policies for their restrictive, 'lowest common denominator' nature, and has therefore called for more supranationalisation of this policy area. The EP has been particularly critical of Commission initiatives being subject to long delays in the Council of Ministers, or being watered down or even completely abandoned by the Commission itself in the belief that they would not otherwise receive unanimous approval (Geddes, 2003: 41-42). Moreover, it has particularly been concerned with fighting racism and xenophobia, and has encouraged the Commission to produce proposals to this end (Geddes, 2003: 142-143). In fact, since the 1970 s, the EP has itself produced reports promoting integration, social policies and rights for resident migrants, and highlighting the need to fight racism and racial discrimination. The EP has also, due to its budgetary powers, been able to fund initiatives such as the 'European Year against Racism' (Lahav, 2004: 63-65).

Based on the concern about racism and xenophobia in evidence at the 1994 Corfu Council, and the report of the Kahn Comission which proposed binding legislation to combat racism and xenophobia, the EP argued that the Maastricht Treaty should be amended to deal with racial discrimination. The EP's lobbying, along with pressure from the Commission, finally ensured that a clause allowing action against discrimination on the basis of racial or ethnic group as well as gender was included in the Amsterdam Treaty (Geddes, 2003: 14-143). 


\section{Conclusions}

Although 'real live neo-functionalists may [now] be an endangered species', neo-functionalism has proved to be a surprisingly resilient theory considering the dramatic changes and crises that the EC/EU has undergone since the early days of neofunctionalism and has influenced many other, newer theories of European integration (Schmitter, 2002: 18). It can thus be argued that, despite the words of Ernst Haas, the theory as such has never become completely obsolecent even in its most unpopular hours, namely during the stagnation period of the 1970s and, perhaps, the present day.

As this paper has aimed to show, the development of JHA appears to fit fairly well into the neofunctionalist framework, with examples of functional, political and cultivated spillover. Functional spillover in this area principally resulted from the Schengen agreement and the Single Market Project. Political spillover occured due to a combination of competition between national officials, engrenage, public opinion and pressure from pro-migrant and business NGOs. Finally, cultivated spillover originated principally from the Commission, but also from the Court of Justice and the European Parliament.

However, counterveiling forces have also been at work in the development of JHA. Firstly, there has been considerable diversity among the national policies in the areas covered by JHA resulting in some difficulties in harmonisation of and co-operation in these policies. Moreover, pressure from nationalist oriented leaders and/or public opinion in some Member States has led to instances of 'enhanced co-operation, resulting in JHA being often cited as an example of 'Europe a la carte'. It has become even more so following the recent Lisbon Treaty, in which the UK, Ireland, Denmark and Poland were granted new opt-outs, in particular in the areas of police and criminal judicial co-operation (Peers, 2007: 2) (Carrera and Geyer, 2007: 4). However, while such a situation is problematic from the point of view of neofunctionalism, Schmitter's neoneo-functionalism is more accepting of opt-outs and lengthy derogations as it sees the likely finalite politique of the EU as a diverse entity characterised by polycentric and multi-level governance rather than a federal state (Schmitter, 2002: 41).

In addition, significant areas of JHA still remain, to various extents, under national control. Regarding immigration policy, for instance, while 
there is considerable integration in the area of control and regulation of immigration there is very little evidence of supranational, or even intergovernmental, integration in the area of incorporation, including such matters as citizenship policies, education, acculturation and language issues (Lahav, 2004: 49). However, the Commission has also been pushing for integration in these areas and, particularly at the Tampere council, it can be seen to have had a certain amount of success.

In conclusion, though, while it is undeniable that the Member States have had a vital part in the development of the JHA acquis, it cannot be argued that they are the only major players in this policy area. Indeed, cooperation in JHA has increasingly escaped the control of the Member States, first as a result of intergovernmental bargaining and later, and more significantly, as a consequence of increased supranationalisation resulting, at least in part, from neofunctionalist spillover. The recent Lisbon Treaty has developed supranationalisation in this area even further despite the increase in opt-outs granted to certain Member States (Peers, 2007) (Carrera and Geyer, 2007). However, that is not to say that development in JHA cannot be stalled. As neofunctionalists remind us, spillover is not the only possible outcome, and it can be disrupted to cause spillback, a halt or even reversal in integration. This would take a severe crisis. However, it is possible that the most recent and forthcoming enlargements could cause such a shock.

\section{References:}

Apap, Joanna and Carrera, Sergio (2003). 'Progress and Obstacles in the Area of Justice and Home Affairs in an Enlarging Europe'. CEPS Working Document no.194. Retrieved: March 3, 2005 from http://www.ceps.be

Bainbridge, Timothy (2001). The Penguin Companion to European Union. London: Penguin

Caporaso, James A. and. Keeler, John T.S (1995). 'The European Union and Regional Integration Theory'. Carolyn Rhodes and Sonia Mazey (eds.), The State of the European Union Vol.3. Colorado: Lynne Rienner

Carrera, Sergio and Geyer, Florian (2007). Implications of the Reform Treaty for EU Justice and Home Affairs Policies. Retrieved: October 10, 
2007 from http://www.euractiv.com/en/justice/implications-reformtreatyeu-justice-home-affairs-policies/article-166390

Eurobarometer. Flash Eurobarometer 155 (Justice and Home Affairs) Retrieved: October 19, 2004 from: http://europa.eu.int/comm/ publicopinion/flash/fl155_report_en.pdf

Fijnaut, Cyrille (2004). 'Police Co-operation and the Area of Freedom, Security and Justice'. Neill Walker (ed.) Europe's Area of Freedom, Security and Justice. Oxford: Oxford University Press

Geddes, Andrew (2000). Immigration and European Integration: Towards Fortress Europe? Manchester: Manchester University Press

Geddes, Andrew (2003). 'Still Beyond Fortress Europe? Patterns and Pathways in EU Migration Policy'. Queen's Papers on Europeanisation No.4/2003. Retrieved: March 202005 from http://econpapers. repec.org/paper/erpqueens

Groom, A.J. (1994). 'Neofunctionalism: A Case of Mistaken Identity'. Brent F. Nelsen and Alexander C.G. Stubbs (eds.) The European Union: Readings on the Theory and Practice of European Integration. Colorado: Lynne Rienner Publishers

Guiraudon, Virginie (2001). The EU Garbage Can: Accounting for Policy Developments in the Immigration Domain. Retrieved: January 92005 from http://www.eustudies.org/GuiraudonPaper.doc

Guiraudon, Virginie (2004). 'Immigration and Asylum: a High Politics Area'. Maria Green Cowles and Desmond Dinan (eds.), Developments in the European Union 2. Hampshire: Palgrave Macmillan

Hix, Simon (1999). The Political System of the European Union. London: Palgrave Macmillan

Lahav, Gallya (2004). Immigration and Politics in the New Europe: Reinventing Borders. Cambridge: Cambridge University Press

Lindberg, Leon L. (1994). 'Political Integration: Definitions and Hypotheses'. Brent F. Nelsen and Alexander C.G. Stubbs (eds.) The European Union: Readings on the Theory and Practice of European Integration. Colorado: Lynne Rienner Publishers 
Luedtke, Adam (2004), EU Immigration Law, Member State Discretion and Judicial Independence: Will Third Country Nationals Gain Free Movement Rights? Retrieved: June 29 2005from http://www.lisproject.org/immigration/papers/Luedtke.pdf

Luedtke, Adam (2005). Supranational Integration, Free Movement of Persons, and Immigration Politics: The Case of Europe's 'Third Country Nationals. Budapest: Society for Comparative Research

Marsh, Michael (1999). 'Policy Evaluations'. Richard S. Katz and Bernhard Wessels (eds.), The European Parliament, the National Parliament and European Integration. Oxford: Oxford University Press

Mattli, Walter and Slaughter, Anne Marie (1996). Constructing the European Union Legal Systen from the Ground Up: The Role of Individual Litigants and National Courts. Retrieved: July 4, 2005 from: http://econpapers.repec.org:80/paper/erpeuirsc/96_2F56.htm

Monar, Jorg (2000). 'Justice and Home Affairs in a Wider Europe: The Dynamics of Inclusion and Exclusion'. ESRC One Europe or Several Programme Working Paper no.7

Monar, Jorg (2005). 'What Added Value for the 'Area of Freedom, Security and Justice?'Justice and Home Affairs in the Draft Constitutional Treaty'. European Constitutional Review, 2005 Vol.1: 2, Retrieved: July 10,2005 from http://www.asserpress.nl/cata/euconst/EuConst $\%$ 20issue $\% 202 \% 20$ contents.pdf\#search='J\%C3\%B6rg\%20Monar\%20wha t\%20added\%20value'

Moxon-Browne, Edward (2003). New Wine, Old Bottles or Both: Regional Integration in the Mediterranean. Retrieved: Apri 23, 2005 from http://cide.univ.szczecin.pl/mec4/Edward\%20MoxonBrowne.pdf

Niemann, Arne (2005). Dynamics and Counterveiling Pressures of Visa, Asylum and Immigration Policy Treaty Revision: Explaining Change and Inertia from the Amsterdam IGC to the Constitutional Treaty. Retrieved: March 2, 2007 from http://aei.pitt.edu/3079/01/ EUSA2005_paper_A.Niemann_JHA-final.pdf

Niemann, Arne, (2006). 'Explaining Visa, Asylum and Immigration Policy Treaty Revision: Insights from a Revised Neofunctionalist Framework'. Constitutionalism Web-Papers, 1. Retrieved: 
November 12, 2006 from http://www.qub.ac.uk/schools/School ofPoliticsInternationalStudiesandPhilosophy/FileStore/ConWEBFiles/Fil etoupload,38372,en.pdf

Occhipinti, John D (2004). 'Police and Judicial Co-operation'. Maria Green Cowles and Desmond Dinan (eds.), Developments in the European Union 2. Hampshire: Palgrave Macmillan

Peers, Steve (2007). EU Reform Treaty Analysis 1: JHA Provisions. Retrieved: September 20, 2007 from www.statewatch.org/news/2007/ aug/eu-reform-treaty-jha-analysis-1.pdf

Schmitter, Philippe C. (July 2002). 'Neo-Neo Functionalism'. Retrieved: August 10, 2004 from iue.it/SPS/.../PDFFiles/SchmitterPDFfiles/ NeoNeoFunctionalismRev.pdf

Schmitter, Philippe (April 2005). 'Haas and the Legacy of Neofunctionalism'. Journal of European Public Policy, 12.2, 255-272.

Stroby Jensen, Carston (2003). 'Neo-functionalism'. In Michelle Cini (ed.), European Union Politics. Oxford: Oxford University Press

Tranholm-Mikkelsen, Jeppe (1991). 'Neo-Functionalism: Obstinate or Obsolete? A Reappraisal in the Light of the New Dynamism of the EC'.Millenium: Journal of International Studies, 20: 1, 4-6

Uçarer, Emek M (May 2001). 'From the Sidelines to Center Stage: Sidekick No More? The European Commission in Justice and Home Affairs', European Online Integration Papers (EOIP) Vol.5 No.5. Retrieved: March 82005 from http://eiop.or.at/eiop/texte/2001-005a.htm

Walker, Neil (2004). 'In Search of the Area of Freedom, Security and Justice: A Constitutional Odyssey'. Neil Walker (ed.) Europe's Area of Freedom, Security and Justice. Oxford: Oxford University Press

Wessels, Bernhard (1999). 'European Parliament and Interest Groups'. Richard S. Katz and Bernhard Wessels (eds.), The European Parliament, the National Parliament and European Integration. Oxford: Oxford University Press 